\title{
Reproductive Biology of Sepia pharaonis Ehrenberg, 1831(Cephalopoda: Sepioidea) from the Suez Gulf (Red Sea), Egypt.
}

\author{
Rafik Riad ${ }^{1}$; Manal Atta ${ }^{2}$; Youssef Halim ${ }^{2}$ and Noha ELebiary ${ }^{1}$ \\ 1- Marine Environment Division, National Institute of Oceanography and Fisheries (NIOF), \\ Alexandria Branch, Egypt. \\ 2- Oceanography Department, Faculty of Science, Alexandria University, Egypt.
}

\section{ABSTRACT}

Reproductive biology of males and females of Sepia phraonis were investigated from samples obtained from commercial catch caught by local fishermen using trawling nets. The samples were seasonally collected (individuals) between winter 2014 to autumn 2014. The results of sex ratio indicated that females outnumbered males. The mean size at first maturity was $7 \mathrm{~cm}$ and $8.6 \mathrm{~cm}$ dorsal mantel length (ML) for males and females respectively Based upon morphological features of the gonads and nidamental gland color change in female, five and four maturity stages for males and females were described, respectively. Depending on the proportion of each maturity stage, as well as various maturity indices (gonado-somatic index, G.S.I and nidamental-somatic index, N.S.I) the spawning season was found to take place during spring and summer and sometimes extends to autumn. So, it is recommended to reduce fishing activity during these periods.

Keywords: Sepia pharaonis, reproductive biology . Suez Gulf, Red Sea, Egypt

\section{INTRODUCTION}

Class Cephalopoda comprises Cuttlefishes, Squids, Octopuses and Nutili. It embraces about 1000 known species and constitutes about 2.07\% of phylum Mollusca (Hassan, 1974). Cephalopoda represents a significant worldwide fishery resource. According to Roper et al. (1984) the world total catch of cephalopod consists of $71.8 \%$ were squids; $13.6 \%$ cuttlefish and $14.6 \%$ octopuses. Riad (1993) stated that in the Egyptian Mediterranean waters the cephalopods constitute $9.8 \%$ of the total fish catch of which $61 \%$ are cuttlefishes, $3.5 \%$ octopuses and $0.21 \%$ squids. On the other hand, in the Red Sea Egyptian waters cuttlefishes constitute about $0.69 \%$ from the total fish catch (Riad and Abdelhafez, 2008).

Cephalopod fishery is economically very important, because of its high commercial value in national and international markets (Mehanna et al., 2014). Mehanna et al. (2009) stated that the high protein content of cephalopods and their low fats make them an important and healthy element in human diet either as fresh food or processed products. Samiee et al. (2013) indicated that the dominant fatty acids in muscle tissue are Docosahexaenoic acid (DHA) (32.89\%) and Eicosapentaenoic acid (EPA) (27.68\%). DHA and EPA are Omega-3 fatty acids and essential fats.

The cephalopods represent about $3 \%$ of the total world capture fisheries production that stood at 3.5 million tons in 2003 (FAO, 2005). Among the cephalopods of the family Sepiidae, the pharaoh cuttlefish Sepia pharaonis is widely distributed in the Indo-West Pacific region ranging from Red Sea to Japan and Australia and forms a dominant species in the commercial fisheries (Roper et al., 1984 ; Nesis, 1987). This cuttlefish is the primary fishery in the Suez Canal and the 
most valuable commercial cephalopods in the northern Indian Ocean. However, their reproductive biology, which is essential for fishery management, is poorly known (Gabr et al., 1998).

The major species of cuttlefish in the Gulf of Suez are S. savignyi, S. dollfusi, $S$. pharaonis and $S$. prashadi (Emam, 1983\&1994). It is worth to note that the reproductive biology of the common cuttlefish of the eastern Atlantic and Mediterranean Sea, Sepia officinalis, is now well-known in considerable detail. In contrast, little is known about the biology of Sepia pharaonis. Therefore, the objective of this study is to investigate the reproductive biology of this important species in the Suez Gulf, Red Sea. Information on maturation and spawning of $S$. pharaonis will contribute to knowledge of their population dynamics and management of the stocks.

\section{MATERIALS AND METHODS}

Seasonal specimens of Sepia pharaonis were collected during the period from winter 2014 to autumn 2014 (850 individuals) from commercial trawling vessels of Suez Gulf, Egypt. Samples were frozen and stored for investigation. After thawing at room temperature, the sex was determined by checking the presence of the left arm IV hectocotylized (modified arm) in male.

Sex ratio: number of males and females, individuals of each sex, was carried out.

Length at first maturity was determined which is the mantle length at which $50 \%$ of the Sepia pharaonis are mature (Snedecor, 1956).

The indices of reproduction. The indices of reproductive status were collected according to Joy (1989) and Pierce et al., (1994). Gonado-somatic Index (GSI) for both sexes and Nidamental gland-Somatic Index (NSI) for the females were calculated as follows:

$$
\begin{gathered}
\mathrm{GSI}=\mathrm{G} . \mathrm{Wt}^{*} 100 / \mathrm{To} . \mathrm{Wt} \\
\mathrm{NSI}=\mathrm{NG} . \mathrm{Wt}^{*} 100 / \text { To. Wt }
\end{gathered}
$$

Where to. Wt is total body weight; G. Wt is the gonad weight; NG. Wt is the nidamental gland weight.

Maturity stages: According to Mangold (1983) male maturity stages were identified by the presence of spermatophores in spermatophoric sac. On the other hand, female maturity stages were identified according to Richard (1967); the egg diameter was measured, the Nidamental glands length (NL) and the color of accessory Nidamental glands were determined.

Fecundity: For fecundity, egg clusters were removed out of gonads and placed in Petri dish containing water. Large reticulated, eggs were only counted as they considered developing eggs. The total number of eggs was estimated from an exact count of all eggs of each individual visually.

\section{RESULTS}

\section{Sex ratio}

Table (1): illustrates the ratio of Sepia pharaonis males to females of the studied specimens. It appears that females outnumber males during all seasons. 
Table 1: Seasonal ratio of male to female individuals of Sepia pharaonis.

\begin{tabular}{|l|c|c|c|l|l|}
\hline Seasons & Total no & sex & no & \% & ratios \\
\hline spring & 137 & Male & 16 & 11.679 & \\
& & female & 121 & 88.321 & $\mathbf{1}: \mathbf{5 . 5 8 7}$ \\
\hline summer & 494 & Male & 75 & 15.182 & \\
& & female & 419 & 84.321 & $\mathbf{1}: \mathbf{2 . 8 6 1}$ \\
\hline Autumn & 139 & Male & 36 & 25.899 & $\mathbf{1}: \mathbf{2 . 6 3 6}$ \\
& & female & 103 & 74.101 & \\
\hline winter & 80 & male & 22 & 27.5 & $\mathbf{1}: \mathbf{5 . 5 8 7}$ \\
& & Female & 58 & 72.5 & \\
\hline All year & $\mathbf{8 5 0}$ & Male & $\mathbf{1 4 9}$ & $\mathbf{1 7 . 5 2 9}$ & $\mathbf{1}: \mathbf{4 . 7}$ \\
& & female & $\mathbf{7 0 1}$ & $\mathbf{8 2 . 4 7 1 1}$ & \\
\hline
\end{tabular}

\section{Length at first maturity}

Size at first maturation is defined as the size at which 50 percent of the individuals are maturing or mature (Bakhayokho, 1983). In the present study, the size at first sexual maturity for males and females of Sepia pharaonis was estimated to Fig. (1).

Length at first maturity of Sepia pharaonis

Female gonado-somatic index for Sopia pharaonis

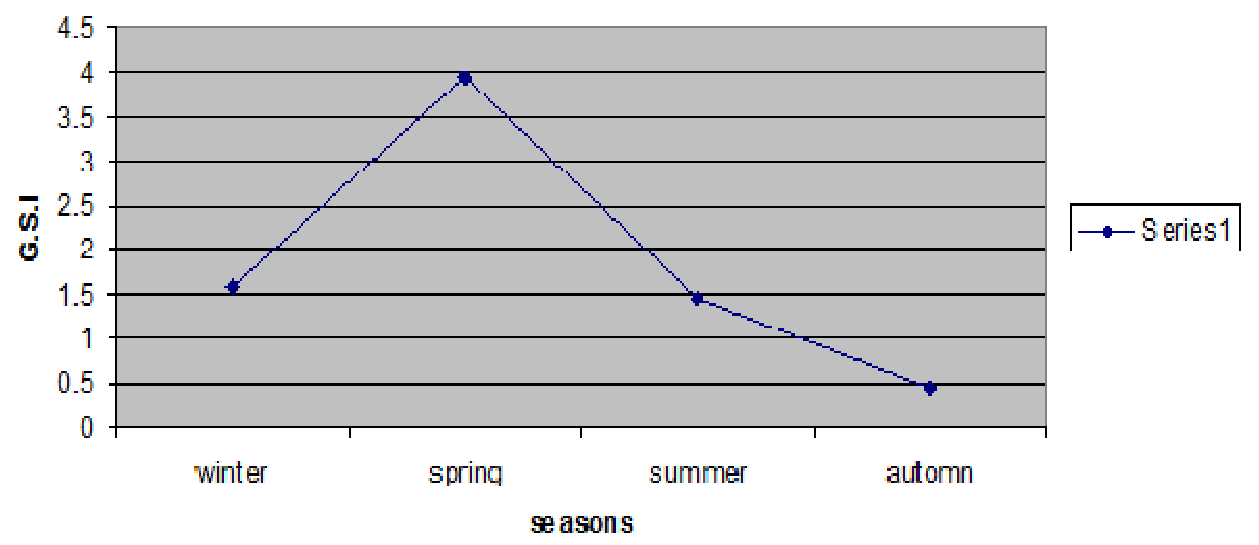

Fig. 1: Length at first maturity of females and males of Sepia pharaonis.

\section{Maturity index}

Gonado Somatic Index (G.S.I). It is worth to note that the spawning season can be predicted from seasonal variations in gonadal size .The start of a gonadal increase in gonado-somatic index (GSI) is an indication of the onset of the breeding season. The Gonado-Somatic Index attains its maxima during breeding time. Gonado-somatic index minimal values were attained during autumn. The G.S.I for males and females clarified gradual increase starting in winter and peaked during spring (Fig. 2), indicating that spawning season of both sexes occurs during early spring, summer and extend to autumn. 


\section{Female gonado-s omatic index for Sepia pharaon is}

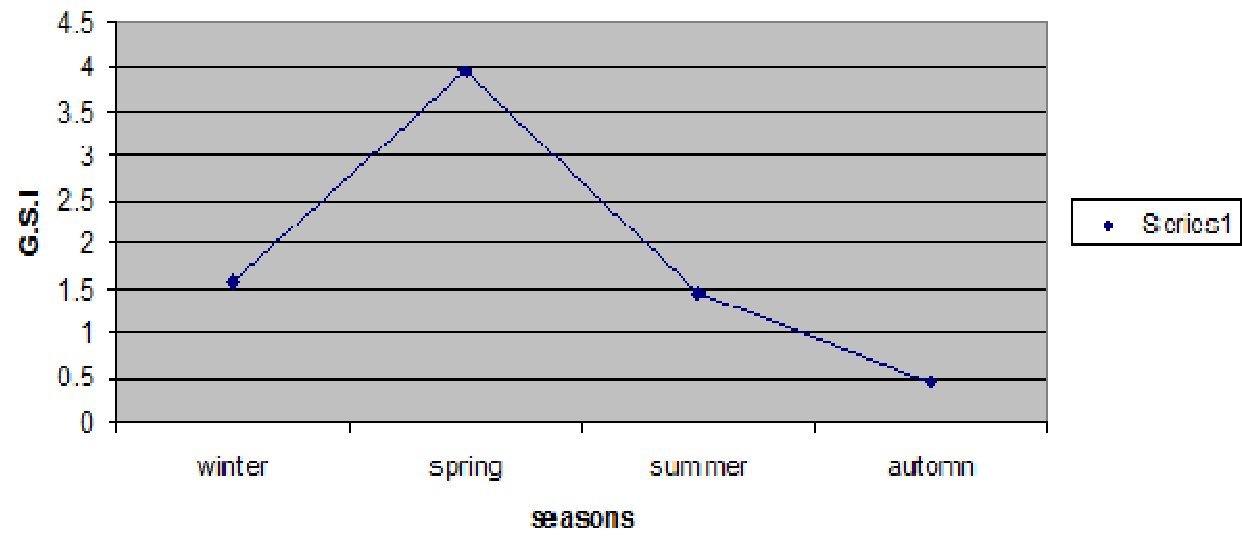

Female gonado-somatic index for Sepia pharaonis

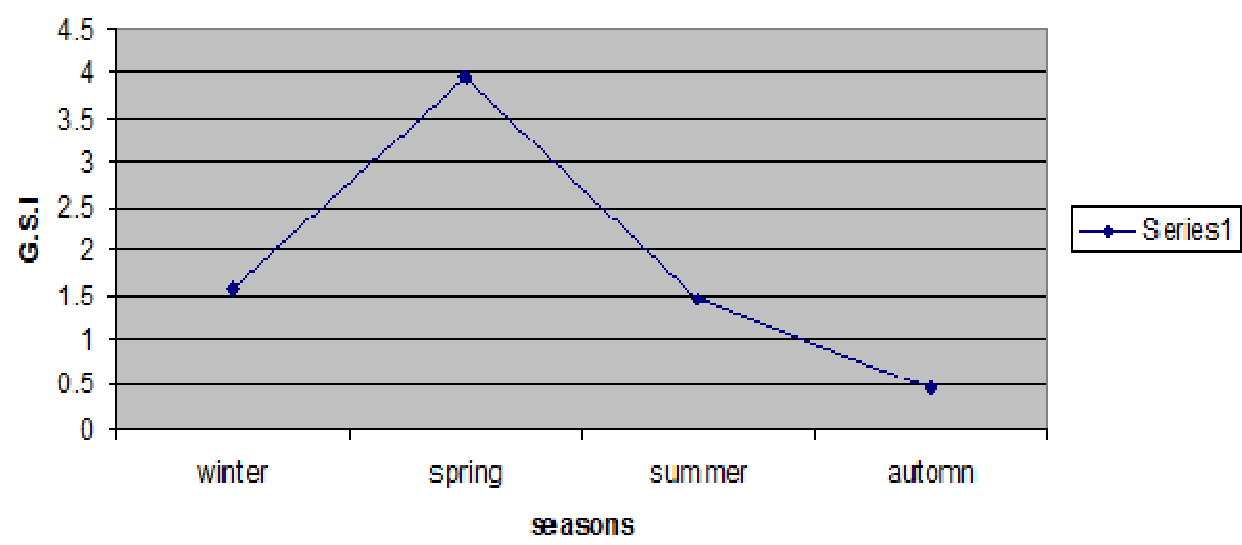

Fig. 2: Gonado Somatic Index for males and females of Sepia pharaonis.

\section{Nidamental gland-Somatic Index N.S.I}

It is to be noted that at the time of Sepia pharaonis spawning the females possess enlarged nidamental gland. The variations in the N.S.I could therefore, like those of the G.S.I, reflect the breeding cycle and spawning intensity.

The N.S.I of females was determined from fig (3) showing the seasonal N.S.I variation running more or less parallel to those of the G.S.I seasonal variations.

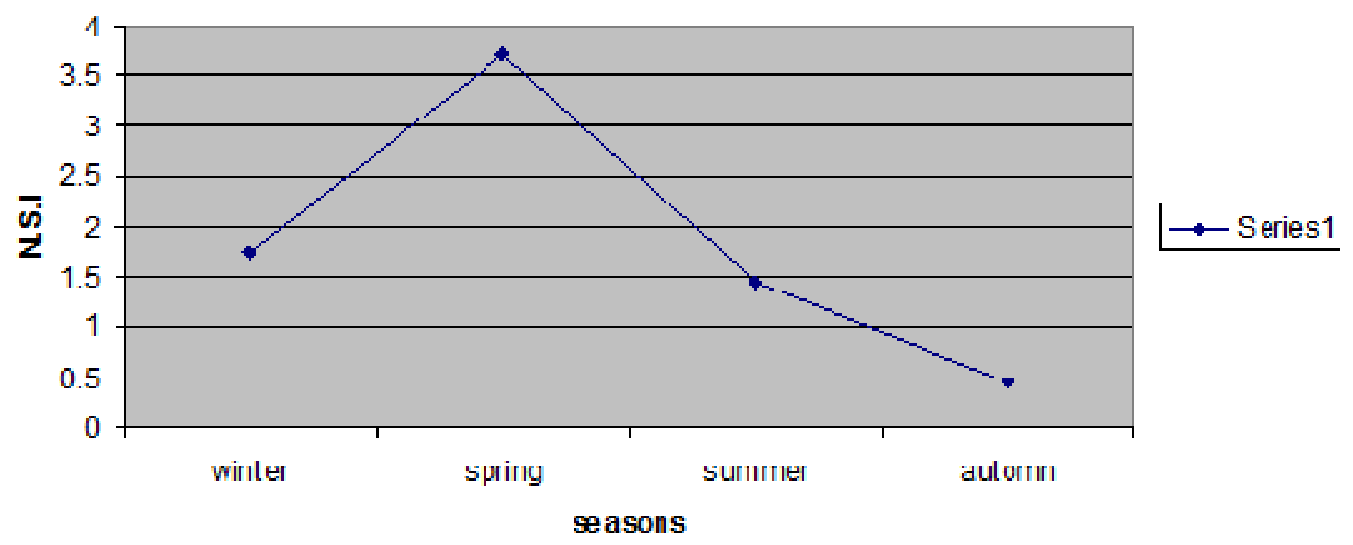

Fig. 3: Nidamental Somatic Index for females of Sepia pharaonis. 


\section{Maturity stages}

In order to define different maturity stages in males we have to detect the presence of spermatophores in Needham's sac and accessory nidamental gland color and egg size in females. The present results obtained classified maturity as five stages for males (immature, maturing, mature ripe and spent) and four stages for females (immature, maturing, mature, and ripe) as shown in Table (2).

Table 2: Sexual maturity stages of Sepia pharaonis

\begin{tabular}{|c|c|c|}
\hline Stage & Female & Male \\
\hline Stage 1 immature & $\begin{array}{l}\text { - } \text { Ovary very small, white color } \\
\text { - Egg cluster very small, occupy the } \\
\text { posterior part of mantle as a patch, no } \\
\text { reticulated eggs appear, diameter }<1 \\
\text { - Nidamental gland very small, accessory } \\
\text { nidamnetal gland with translucent, } \\
\text { white to light creamy color (Fig. 4). }\end{array}$ & $\begin{array}{l}\text { - Testis small } \\
\text { - Needham's sac small and } \\
\text { transparent in color, } \\
\text { with no visible } \\
\text { spermatophore, white } \\
\text { fluid only }\end{array}$ \\
\hline Stage II maturing & $\begin{array}{l}\text { Ovary occupies half of posterior body } \\
\text { cavity, gonad creamy in color } \\
\text { Egg cluster, occupies the posterior part } \\
\text { of the mantle as a large patch with few } \\
\text { visible reticulated eggs, diameter } 1-3,4 \\
\text { mm } \\
\text { - Nidamnetal gland large, slightly oval in } \\
\text { shape, accessory nidamnetal gland with } \\
\text { creamy to yellow color (Fig. 5). }\end{array}$ & 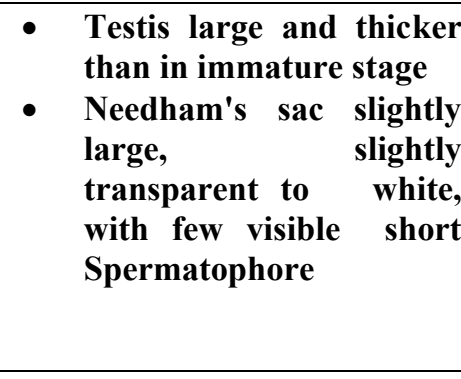 \\
\hline Stage III mature & $\begin{array}{l}\text { - Ovary very prominent occupies entirely } \\
\text { the posterior part of mantle cavity } \\
\text { Large egg cluster occupies the posterior } \\
\text { part, with many recticulated eggs, } \\
\text { diameter } 1-5 \mathrm{~mm} \\
\text { - Large nidamnetal gland and thick, oval, } \\
\text { accessory nidamnetal gland yellowish to } \\
\text { orange in color (Fig. 6). }\end{array}$ & $\begin{array}{ll}\text { - } & \text { Testis large and fully } \\
\text { developed } & \\
\text { - } & \text { Needham's sac fully } \\
\text { packed with developed } \\
\text { spermat-ophores, with } \\
\text { tall spermatophore }\end{array}$ \\
\hline Stage VI ripe & $\begin{array}{l}\text { - Ovary very prominent occupies all the } \\
\text { posterior part of mantle cavity with } \\
\text { heavy gelatinous secretion } \\
\text { - egg cluster very large with heavy gelatin } \\
\text { with fully developed eggs (smooth or } \\
\text { reticulated), diameter } 2-8 \mathrm{~mm} \\
\text { - Nidametal gland enlarged, very thick, } \\
\text { accessory nidamnetal gland with } \\
\text { reddish orange to dark red with visible } \\
\text { red (light, dark) dots or stripes (Fig. } 7 \text { ) }\end{array}$ & $\begin{array}{ll}\text { - } & \text { Testis fully developed } \\
\text { - Needham's sac flaccid } & \text { with degenerating } \\
\text { spermatophores } \\
\text { mantle cavity }\end{array}$ \\
\hline Stage V spent & & $\begin{array}{l}\text { As the immature stage but } \\
\text { large gonad and large mantle } \\
\text { length, nedham's sac empty } \\
\text { only contain white fluid no } \\
\text { spermatophore available }\end{array}$ \\
\hline
\end{tabular}



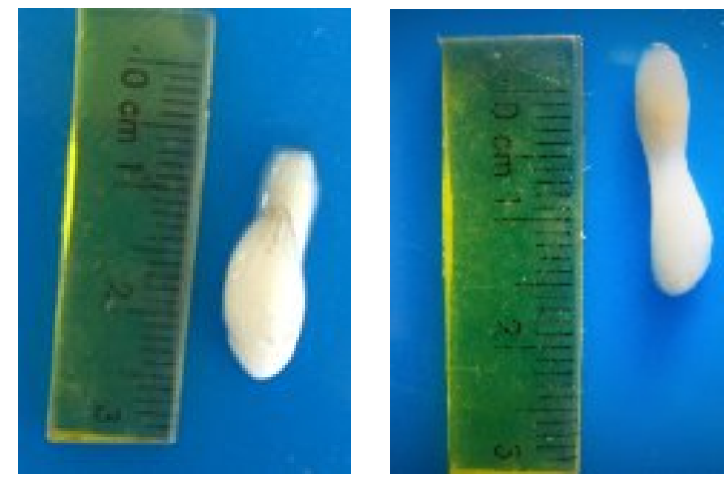

Fig. 4: Stage I immature, white to light creamy accessory nidamental gland.

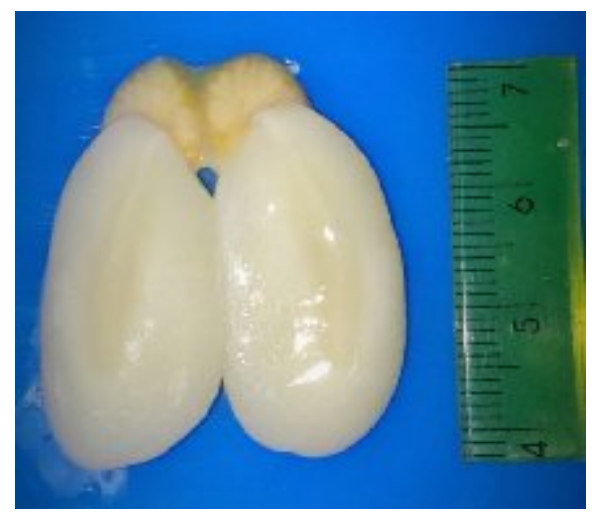

Fig. 5: Stage II maturing, creamy to yellow accessory nidamnetal gland.

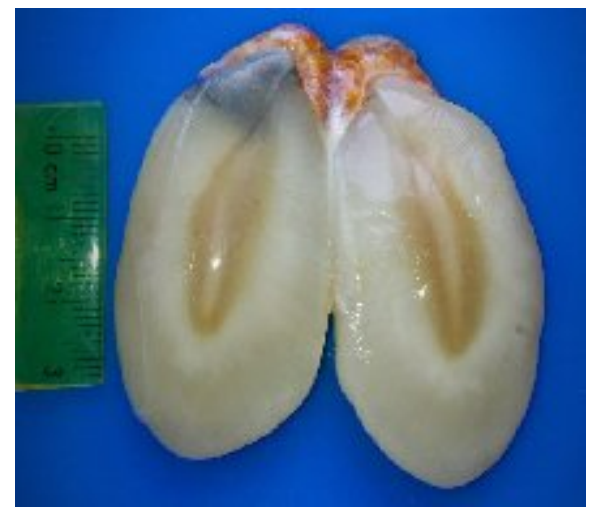

Fig. 6: Stage III mature, yellow to orange accessory nidamnetal gland.
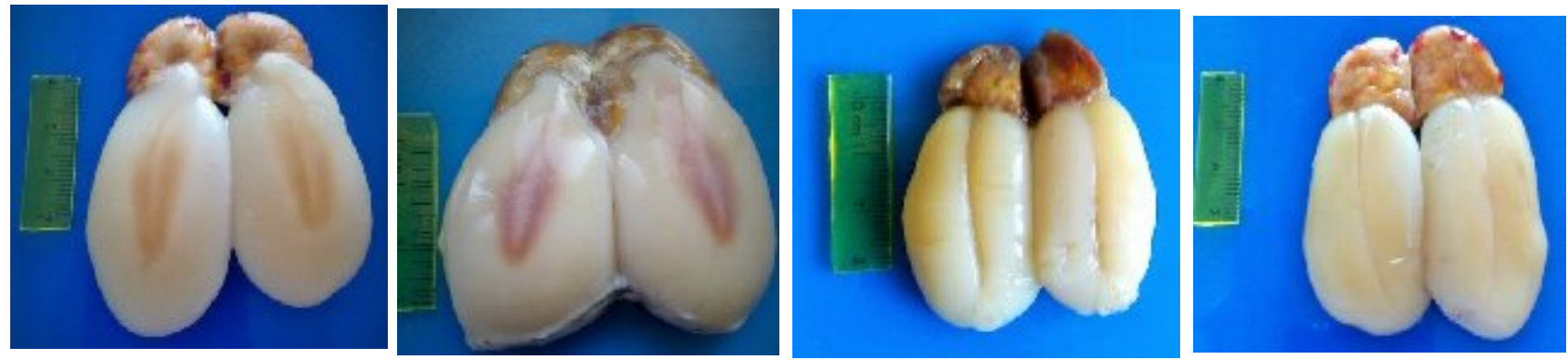

Fig. 7: Stage VI ripe, reddish orange to dark red accessory nidamtnal gland. 


\section{Fecundity}

The minimum fecundity range in the present study has been determined by counting the eggs in the egg clusters (Fig. 8) and it was 102 for $9.5 \mathrm{~cm}$ mantle length and the maximum was 616 for $12.9 \mathrm{~cm}$ mantle length.
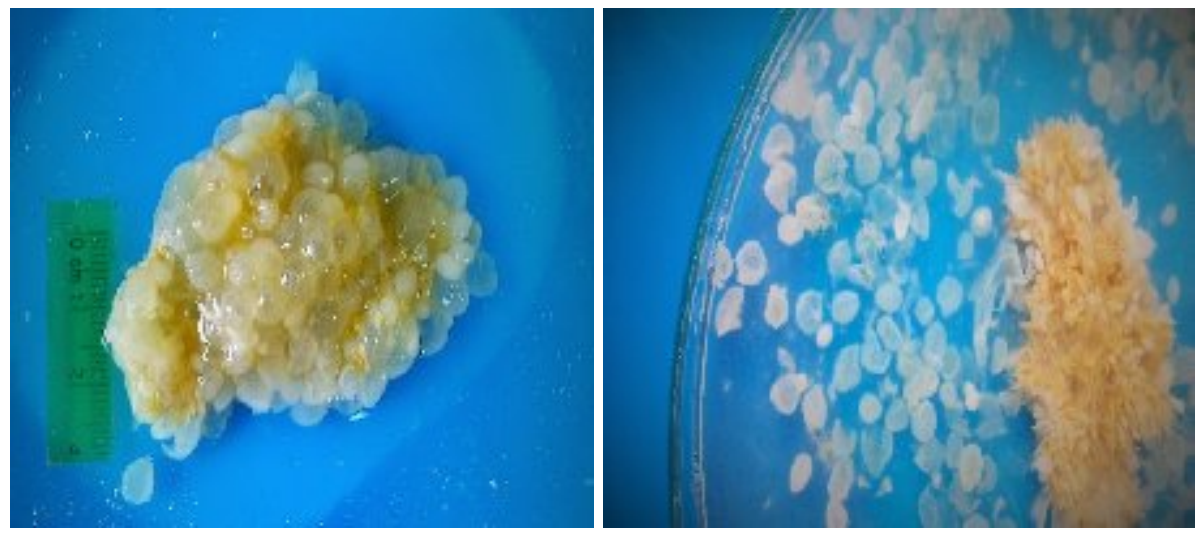

Fig. 8: Egg cluster of Sepia pharaonis.

\section{DISCUSSION}

\section{Length at first maturity}

The present work investigation revealed that the length at first maturity for males and females Sepia pharaonis was estimated to be $7 \mathrm{~cm}$ ML and $8.6 \mathrm{~cm} \mathrm{ML,}$ respectively.

Data observed from other authors revealed that the length at first maturity for Sepia pharaonis, markedly vary at different locations. Sanders and Bouhlel (1981) found that at Yemeni waters the length at first maturity for the species was $20 \mathrm{~cm}$. Bouhlel and Musaibli (1985) reported the length at first maturity for the same species to be $25 \mathrm{~cm}$. On the other hand, results obtained for female Sepia pharaonis from Indian waters is $16 \mathrm{~cm}$,( Silas et al., 1986). Gabr (1998) estimated the first maturity at $6.1 \mathrm{~cm}$ and $12.2 \mathrm{~cm}$ for males and females, respectively, for the same species collected from the Suez Canal, Egypt. Mehanna et al. (2009) determined the length at first maturity and found it to be $8.5 \mathrm{~cm}$ in S. pharaonis from Suez Gulf. Al-Marzouki et al. (2009) studied Sepia pharaonis from the Arabian Sea off Oman, and estimated that the length at first maturity for females was $20.2 \mathrm{~cm} \mathrm{ML}$, and $19 \mathrm{~cm}$ for males. Mehanna et al. (2014) found that the length at first maturity for $S$. pharaonis from omani coast Arabian sea, was $19.6 \mathrm{~cm}$.

This difference may be due to the length range of samples used in each study. As $S$. pharaonis is suspected to be a complex of three to five species or Subspecies (Norman, 2000; Anderson et al., 2007), this may be the reason for the differences encountered in length at first maturity and spawning in different regions.

\section{Maturity stages}

In the present study, five stages were recognized for males (immature, maturing, mature, ripe and spent) according to the presence of spermatophore in the Nedham's sac. Four stages for females (immature, maturing, mature, ripe) for Sepia pharaonis were defined according to the gross morphology of the gonad and the color of the accessory nidamental glands for females. Gabr et al. (1998) recorded 4 stages of sexual maturity for both species Sepia pharaonis and Sepia dollfusi according to the gross morphology of the gonads and by the microscopic development in the accessory gland. 
It's worth to note that the above mentioned results regarding maturity stages obtained by Gabr et al. (1998) slightly differs from that obtained during the present study. Females of the present work exhibited marked red color of the accessory nidamnetal gland in ripe stage which is not mentioned by Gabr et al. (1998) at the same stage. Besides, five stages of male maturity was assigned during the present work in contrast to only four found by Gabr et al. (1998)

\section{Maturity index and spawning season}

In the present study N.S.I values were found minimal in autumn and gradually increase attaining its highest value in spring which confirms the previous conclusion from the G.S.I study that spawning season occurs during early spring, summer and extends to autumn. The spawning season of Sepia pharaonis in the present study extend from early spring, summer and extend to autumn with a peak at spring.

Voss and Williamson (1971) have been reported between March and May in Hong Kong, spawning in Sepia pharaonis is restricted to March-May period in Hong Kong waters, and to August - October in the Red Sea (Sanders 1981). A restricted spawning in $S$. pharaonis between August and October in the neighbouring Yemeni waters (Sanders and Bouhlel, 1981). Silas et al. (1986) investigated that spawning occurs from October to April in general on both coasts of India, sometimes extending up to August. Nair et al. (1993) observed in both coasts of India that Cuttlefishes of both sexes' with mature gonads were noted in several months indicating that spawning is not restricted to any season but extended over a period of time. According to Gabr et al. (1998), the spawning season of Sepia pharaonis in the Suez Canal, Egypt takes place from March to June. Abdussamad (2004) stated that the spawning season of Sepia pharaonis from Kakinada along the east coast of India was found to be during August/march (summer/spring) with two peaks during November and December (winter). AL Marzouqi et al. (2009) stated that in the Arabian Sea off Oman, the spawning of Sepia pharaonis during August-December (summer-winter) and April-May (spring). Sundaram (2014) stated that the spawning season for Sepia pharaonis from north west coast of India takes place from February to may (winterspring). Ghazvineh et al. (2012) recorded that the spawning season of Sepia pharaonis from the Persian Gulf covers the whole months with two maximum peaks in May and June (spring-summer). Sasikumar et al., (2013) recorded that the peak of spawning of Sepia pharaonis in the Indian waters (Eastern Arabian Sea) is reported in October/November (Autumn). Sasikumar et al. (2013) stated that the spawning season of Sepia pharaonis from the Eastern Arabian sea is reported during October/ November (Autumn) and in February/March (winter). Thus it is clear from the above mentioned results that there is marked variations in the spawning season of Sepia pharaonis regarding different localities, for the same species. Differences were seen between spawning seasons in various ares because of various ecological conditions and effective factor on spawning as food availability (Ghazvineh et al., 2012).

However, there is elasticity in the spawning season of $S$. pharaonis from different regions (Norman, 2000). This indicates that the spawning season and the reproductive peak of $S$. pharaonis are remarkably flexible and probably this may be attributed to environmental conditions prevailing as Mangold-Wirz (1963) considered temperature and light as the most important external factors that influence sexual maturation in cephalopods.

\section{Sex ratio}

In the present study females Sepia pharaonis were dominant with a sex ratio of 4.7:1. In spring, out of a total 137,16 were males $(11.679 \%)$ and 121 were females $(88.321 \%)$. In summer, out of a total 494,75 were males $(15.182 \%)$ and 419 were 
females $(84.321 \%)$. In autumn, out of a total 139 collected animals, 36 were males $(25.899 \%)$ and 103 were females $(74.101 \%)$. In winter, out of a total 80,22 were males $(27.5 \%)$ and 58 were females $(72.5 \%)$.

Silas et al. (1986) Reported that sex-ratio in S. pharaonis is highly variable, There was a great numerical difference in the sex-ratio during most part of the year and females dominated over males in the trawl catches from the Bay of Bengal and in the hook and line fishery in the Arabian Sea. Ayoama and Nguyan (1989) found that the sex ratio of the same sp with mantle length below $30 \mathrm{~cm} \mathrm{1:1} \mathrm{in} \mathrm{Yemeni} \mathrm{waters,}$ while all those larger than $30 \mathrm{~cm}$ are males and the largest one is about $43 \mathrm{~cm}$, reasons for the absence of large females may due to different growth rate and shorter life span. According to Nair et al. (1993) during certain months, only males were landed by the trawlers off Visakhapatnam from the Bay of Bengal from Indian waters. Persian and Vallinassab (1994) found that the proportion of males to females were 70:30 in waters of Sistan and Baluunchestan (Iran). Sundaram (2014) recorded that the females were dominant with sex ratio 1.24:1 for Sepia pharaonis from North West of India. Ghzvineh et al. (2012) noted that that $70 \%$ of population was males and $30 \%$ was female.

These difference in sex ratio from different location may due to sampling method, The reasons for dominance of females over males in the present work study cannot be explained as the data obtained was only restricted for one year. Further studies for the Egyptian waters have be carried out in order to understand Whether or not there is sex segregation in different seasons and sizes of the cuttlefish that was targeted by specific gear

Fecundity

In the present study, ovum sizes vary from less than $1 \mathrm{~mm}$ to about $40 \mathrm{~mm}$. The minimum range fecundity in the present study was (102) for $9.5 \mathrm{~cm}$ mantle length and the maximum was (616) for $12.9 \mathrm{~cm}$ mantle length for Sepia pharaonis.

According to Gabr et al. (1998) Sepia pharaonis from the Suez Canal exhibited relatively more fecundity than other Cuttlefishes. Sepia pharaonis is relatively more fecund than $S$. dollfusi. For example, the number of ova in $S$. pharaonis of $140 \mathrm{~mm}$ ML was 730 compared to 273 ova in a female $S$. dollfusi of a similar size.

Boletzky, (1983) Compared S. pharaonis with the common Mediterranean cuttlefish Sepia officinalis as they share a similar size and life history. He found a maximum fecundity of $S$. pharaonis estimated at 517-1525 ova for females of 110$240 \mathrm{~mm}$ mantle length, respectively, and appears comparable to various fecundity estimates in S. officinalis. Mangold-Wirz (1963) reported that a single female of similar size may lay $\approx 200$ - 550. Richard (1971) indicated a similar fecundity value (150-500) for $S$. officinalis hierredda from the English Channel. Persian and Vallinassab (1994) recorded 500-700 ova for the same sp from Iranian water. Ghzvineh et al. (2012) found that Total number of ova in spawning female of Sepia pharaonis in Persian Gulf ranged from 53 in mantle length $19.8 \mathrm{~cm}$ and body weight $815 \mathrm{gm}$ to 1589 in a female with $25.4 \mathrm{~cm}$ mantle length and body weight $1660 \mathrm{gm}$. Chembian and Mathew (2011) reported that The total number of maturing and matured ova in the pre-spawning and spawning female $S$. pharaonis (stage III and IV) ranged from 146 in a female of $161 \mathrm{~mm}$ ML to 1400 in a female of $259 \mathrm{~mm}$ ML. In spite of these enormous size differences depending on the species, the basic pattern of embryogenesis is the same in all cephalopods (Iglesias et al., 2014). 


\section{RECOMENDATIONA}

It's worth to note that this is the first study regarding Sepia pharaonis that dwells the Egyptian Red Sea waters, in order to clarify its biological status. Hence it's essential to carry out further additional investigations, so as to evaluate the following:

1) Percentage of the species catch compared to the total cephalopod catch, in order to be aware with its stock assessment.

2) To find out whether or not the species has migrated via Suez Canal to the Mediterranean water similar to Sepia dollfusi (Riad, 2015), as they were frequently encountered altogether in the same catch.

3) Evaluating the species nutritional value.

4) Prevention of fishing operations during the spawning season which mainly occurred during spring and summer.

\section{REFERENCES}

Abdussamad, E. M.; Meiyappan, M. M. and Somayajulu, K. R. (2004). Fishery, population characteristics and stock assessment of cuttlefishes, Sepia aculeata and Sepia pharaonis at Kakinada along the east coast of India. Bangladesh J. Fish. Res., 8(2):143- 150.

AL Marzouqi, A.; Jayabalan, N. and Al-Nahdi, A. (2009). Biology and stock assessment of the pharaoh cuttlefish, Sepia pharaonis Ehrenberg, 1831 from the Arabian Sea off Oman. Indian J. Fish., 56(4): 231-239.

Anderson, F.E.; Valinassab, T. ; Ho, C.; Mohamed, K.S.; Asokan, P. K. ; Rao, G.S.; Nootmorn, P.; Chotiyaputta, C.; Dunning, M. and Lu, C. (2007). Phylogeography of the Pharaoh Cuttle Sepia pharaonis Based on Partial Mitochondrial 16S Sequence Data. Southern Illinois University Carbondale publications.

Aoyama, T. and Nguyen, T. (1989). Stock assessment of cuttlefish off the coast of People's Democratic Republic of Yemen. J. Shimonoseki Univ. Fish., 37: 61112.

Bakhayokho, M. (1983). Biology of the cuttlefish Sepia officinalis hierredda off the Sengalese coast. In: Caddy, J.F. (Ed.), Advances in Assesment of World Cephalopod Resource. FAO Fish. Tech. Paper 231, pp. 204-263.

Bouhlel, M. and Musaibli, A. (1985). Second revision of stock assessment of cuttlefish Sepia pharaonis inhabiting the People's Democratic Republic of Yemen waters, FAO, Field Document, FI: RAB/83/023/INT/19.

Chembian, A.J. and Mathew, S. (2011). Migration and spawning behaviour of the pharaoh cuttlefish Sepia pharaonis Ehrenberg, 1831 along the south-west coast of India. Indian J. Fish., 58(3):1-8.

Emam, W. M. (1983). Morphometric studies on three species of the genus Sepia from the Red Sea. Bulletin of the Institutes of Oceanography and Fish., 9: 341-346.

Emam, W. M. (1984). Biological studies on some cephalopods from the Egyptian waters. M. Sc. thesis, Zoo. Dep., Fac. Sci., Ain Shams Univ., 235 pp.

FAO, (2005). Species Catalogue for Fishery Purposes, 4: 105-109.

Gabr, H.R.; Hanlon, R.T.; Hanafy, M.H. and El-Etreby, S.G. (1998). Maturation, fecundity and seasonality of reproduction of two commercially valuable cuttlefish, Sepia pharaonis and Sepia dollfusi, in the Suez Canal. Fish Res., 36: 99-115. 
Ghazvineh, L.; Valinassab, T.; Savari, A. and Ghobadiyan, F. (2012). Reproductive Biology of the Pharaoh Cuttle Sepia pharaonis in the Persian Gulf. World Journal of Fish and Marine Sciences, 4(3): 313-319.

Hassan, A. K. (1974). Studies on bottom Molluscs (gastropods and bivalves) in Abou Kir Bay. M. Sc. Thesis, Facul., Sci, Alex. Univ. 319 pp.

Iglesias, J.; Fuentes, L. and Villanueva, R. (2014). Cephalopod Culture. Springer, Netherlands. 494 pp.

Joy, M. (1989). The fishery biology of ommastrephid squid in scottland water. MSc Thesis, University of Aberdeen, $118 \mathrm{pp}$.

Mangold-Wirz, K. (1963). Biologie des Cephalopodes benthiques et nectoniques de la Mer Catalane. Vie Milieu , 13: 1-285.

Mangold, K. (1983). Octopus vulgaris. In: Cephalopod life cycles. Academic press, London. I: 335- 364.

Mehanna, S. F., Hegazi, M. M. and El-Sherbeny, A. S. (2009). Stock assessment and management of the cuttlefish Sepia pharaonis (Mollusca: Cephalopoda) in the Gulf of Suez. Egyp. J. Aquat. Biol. Fish., 13 (4): 421-431.

Mehanna, S.F.; Al-Kharusi, L. and Al-habs, S. (2014). Population dynamics of the pharaoh cuttlefish Sepia pharaonis (Mollusca: Cephalopoda) in the Arabian Sea coast of Oman. Indian J. Fish., 61(1):7-11.

Nair, K. P.; Srinath, M.; Meivappan, M. M.; Rao, K.S. ; Sarvesan, R.; Vidyasagar, K.; Sundaram, K. S.; Rao, O. S.; Upton, A. P.; Natarajan, P.; Radhakrish, G.; Mohamed, K.S.; Narasimham, K.A.; Balan, K. ; Kripa, V. and Sathianandan, T.V. (1993). Stock assessment of the pharaoh cuttleflsh Sepia pharaonis. Indian J. Fish., 40 (1-2): 85-94.

Nesis, K. N. (1987). Cephalopods of the world. Squid, cuttlefishes, octopuses, 351 pp., Neptune City, NJ: T.F.H. Publications Inc., Ltd.

Norman, M. D. (2000). Cephalopods, a world guide: Pacific Ocean, Indian Ocean, Red Sea, Atlantic Ocean, Caribbean, Arctic, Antarctic. Conch Books, Hackenheim, Germany, 320 pp.

Persian. and Vallinassab, T. (1994). Final report the study of biology of Sepia pharaonis and identification of cephalopoda, Persian Gulf. Fisheries Research Center, 65 pp.

Pierce, G. J.; Boyle, P.R.; Hastie, L. C. and Key, L. (1994). The life history of Loligo forbesi (Cephalopoda: Loliginidae) in Scottish waters. Research , 21: 17-41.

Riad, R. (1993). Studies on cephalopod molluscs of the Mediterranean waters of Alexandria. M. Sc. Thesis, Ocean. Dept., Fac. Sci., Alex. Univ., 246 pp.

Riad, R. and Abd El-Hafez, S. M. (2008). Bio-Economic study of squid from Egyptian Red Sea. Egypt. J . of Aquat. Research, 34 (2): 316- 329.

Riad, R. (2015). First record of the cuttelfish sepia dollfusi (cephalopoda: sepioidea) from the Egyptian Mediterranean water. Egypt. J. Aquat. Biol. \& Fish., 19(3): $1-7$.

Richard, A. (1971). Contribution a Á l' eÂtude expeÂrimentale de la croissance et de la maturation sexuelle de Sepia officinalis L. (Mollusque CeÂphalopode). The Áse Doct. Sc. Nat., Univ. Lille. 264 pp.

Richard, A. (1967). Role de la photoperiode dans le determinisme de la maturation genital femelle du Cephalopode de Sepia officinalis L.C.r hebd. Seanc. Acad. Sci., Paris (Serie D), 264: 1315- 1318.

Roper, C. F. E.; Sweeny, M. J. and Nauen, C. E. (1984). Cephalopods of the world. FAO Fisheries Synopsis 3(125). 277 pp. 
Samiee, K.; Darvish, M.; Rustaiyan, A. and Naghdi, N. (2013). Composition of fatty acids and lipid content of liver and muscle tissues of Sepia pharaonis in the Persian Gulf. Nature and Science Vol. 11(2): 78- 81.

Sasikumar, G.; Mohamed, K. S. and Bhat, U. S. (2013) . Inter-cohort growth patterns of pharaoh cuttlefish Sepia pharaonis (Sepioidea: Sepiidae) in Eastern Arabian Sea. Rev. Biol. Trop. (Int. J. Trop. Biol. ISSN-0034-7744), 61 (1): 1-14.

Sanders, M J. (1981). Revised stock assessment for the cuttlefish Sepia pharaonis, taken off the coast of the Peoples'Democratic Republic of Yemen. Project for the development of fisheries in areas of the Red Sea and Gulf of Aden, Cairo, Egypt. RAB/77/008/13, 44 pp. FAO.

Sanders, M. J. and Bouhlel, M. (1981). Interim report of a mesh selection study conduction in the People's Democratic Republic of Yemen on the cuttlefish Sepia pharaonis., UNDP/FAO Project, RAB/77/008/41, 35 pp.

Silas, E.G; Sarvesan, R.; Nair, K. P.; Sastry, Y. A.; Srinivasan, P. V.; Meiyappan, M. M.; Vidyasagar, R.; Rao, K. S. and Rao, B. N. (1985). Some aspects of the biology of Cuttlefishes. In: Silas, E.G. (Ed.) Cephalopod bionomics, fisheries and resources of the Exclusive Economic Zone of India, Bull. Cent. Mar. Fis. Res. Inst., 37: 49-70.

Silas, E. G.; Rao, K.S. , Sarvesan, R.; Nair, K. P.; Vidyasagar, R.; Meiyappan, M. M.; Sastry, Y. A. and Rao, B. N. (1986). Some aspects of the biology of cuttlefishes. Bulletin Central Marine Fisheries Research Institute, 37: 49-70.

Snedecor, G.W. (1956). Statistical methods applied to experiments in Agriculture and biology. Iowa state Univ., Press, U. S. A., 534 pp.

Sundaram, S. (2014). Fishery and biology of Sepia pharaonis Ehrenberg, 1831 off Mumbai, northwest coast of India. J.Mar.Biol.Ass.India, 56(2): 43-47.

Voss, G. L. and Williamson, G. R. (1971). Cephalopods of Hong Kong. Government Press Hong Kong, 138 pp.

\section{ARABIC SUMMARY}

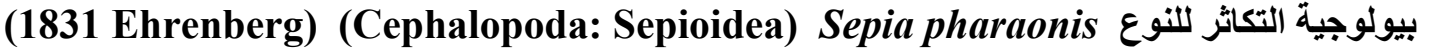 من خليج السويس (البحر الأحمر ) - مصر

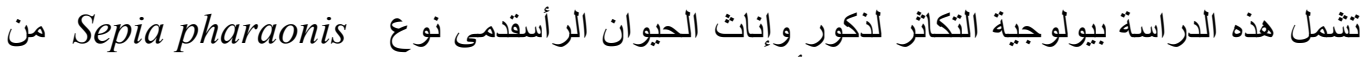

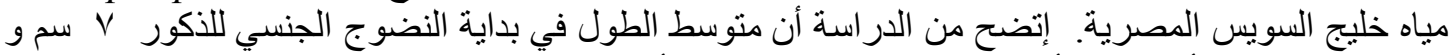

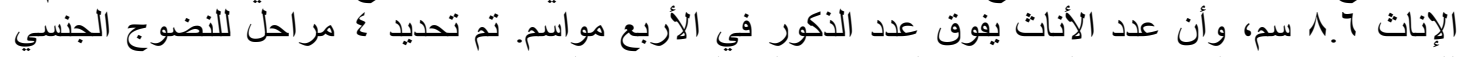

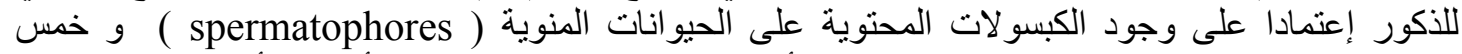

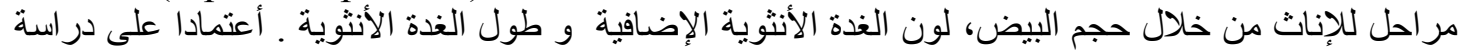

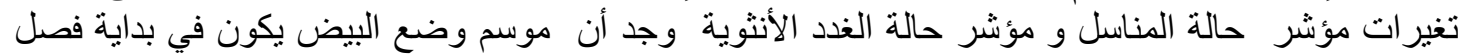

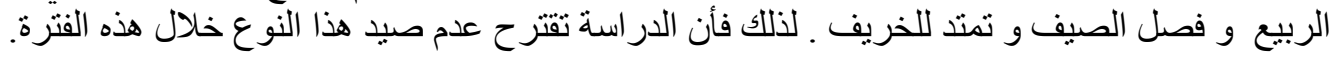

